\title{
Long term measurements of the elemental composition and optical properties of aerosols in Amazonia
}

\author{
A. A. Arana ${ }^{1}, \underline{\text { P. Artaxo }}^{2}$, L. V. Rizzo ${ }^{3}$ and W. Bastos ${ }^{4}$ \\ ${ }^{1}$ Instituto Nacional de Pesquisas da Amazônia - INPA, Manaus, AM, Brazil \\ ${ }^{2}$ Instituto de Física, Universidade de São Paulo, São Paulo, SP, Brazil, artaxo@if.usp.br \\ ${ }^{3}$ Universidade Federal de São Paulo, Campus Diadema, Diadema, Brazil \\ ${ }^{4}$ Universidade Federal de Rondonia, UNIR, Porto Velho, Brazil
}

\begin{abstract}
Aerosols are being collected and analyzed for trace elements in two sites in Amazonia since January 2008. On eof the site, Manaus is located in a very pristine area in Central Amazonia. The site is nt affected directly by any urban plume for thousands of kilometers. A second site is located in Porto Velho, in a region with heavy land use change and deforestation. Optical properties (light scattering ad absorption) are also being measured in order to study the climatic impact of aerosols. It was observed a clear seasonal pattern for both sites, with higher concentrations in the dry season. But the difference in seasonal concentrations observed for Porto Velho is much larger due to stronger anthropogenic influences. In Manaus during the wet season, very low concentrations of heavy metals, maybe the smallest measured in continental regions are reported. Positive Matrix Factorization (PMF) was used to separate the different aerosol components. In general, for fine and coarse mode and wet and dry season, 3 aerosol components could be observed: 1) Natural biogenic aerosol; 2) biomass burning component; 3) Soil dust both locally and long range transported Sahara dust
\end{abstract}

Keywords: Amazon, Atmospheric aerosol, Atmospheric chemistry, Heavy metals, optical properties.

\section{Introduction}

Central Amazonia is one of the few continental sites in the world where we can still observe very little impact of anthropogenic pollution (Davidson et al., 2012). Aerosol particles and trace metals show very low concentrations, because the air masses have travelled about $2.000 \mathrm{Km}$ over pristine rainforest before being measure at sites North of Manaus (Martin et al., 2011).

\section{Materials and Methods}

Aerosol physical and chemical properties were measured in two sites in Amazonia since January 2008. The clean site is at central Amazonia and is located in a pristine Amazonian forest site. A second sampling site is located in Porto Velho, Rondonia, an area strongly affected by land use change and biomass burning emissions. Long term measurements, are being carried out in these two sites, as part of the AEROCLIMA (Direct and indirect effects of aerosols on climate in Amazonia and Pantanal) project. The dataset obtained encompass the first long term aerosol measurements ever performed in Amazonia. In the pristine central Amazonia, measurements were taken at the Cuieiras forest site, tower TT34, with coordinates $2^{\circ} 35^{\prime} 40^{\prime \prime} \mathrm{S}$ and $60^{\circ} 12^{\prime} 33^{\prime \prime} \mathrm{W}$, above the canopy $(45 \mathrm{~m})$, under dry conditions $(\mathrm{RH}<40 \%)$ For site description see Kulmala et al., 2011, Martin et al., 2011. A MAAP 5012 absorption photometer in series with a 3-wavelengths nephelometer (TSI 3563) was used to measure aerosol absorption and scattering, respectively. Aerosol size distributions were measure using a Lund DMPS system, as well as a TSI SMPS system. Aerosol composition, trace elements, $\mathrm{O}_{3}, \mathrm{CO}$ and $\mathrm{CO}_{2}$ that helps to characterize aerosol sources were also measured. In Rondonia, a sampling station was installed close to the city of Porto Velho, in the at $\left(8,69^{\circ} \mathrm{S} ; 63,87^{\circ} \mathrm{O}\right)$. This region has important land use change and biomass burning emissions. In both sites Stacked Filter Units (SFU) are being used to collect aerosol particles in two size fractions: $\mathrm{PM}_{10}$ and $\mathrm{PM}_{2.5}$. The sampling time is 2 to 5 days depending on the aerosol loading in the atmosphere. Gravimetric analysis, black carbon as well as trace elements are being measured in the filters. X-ray Fluorescence using a PanAnalytical EDXRF Epsilon 5 instrument allows the detection of up to 24 trace elements.

\section{Results and Discussion}

In terms of optical measurements, in the pristine 
Amazonian atmosphere, aerosol scattering coefficients ranged between 1 and $200 \mathrm{Mm}^{-1}$ at $450 \mathrm{~nm}$, while absorption ranged between 1 and $20 \mathrm{Mm}^{-1}$ at $637 \mathrm{~nm}$. A strong seasonal behavior was observed, with greater aerosol loadings during the dry season (Jul-Nov) as compared to the wet season (Dec-Jun). Although the forest site is locally well preserved, it receives the influence of regional biomass burning emissions during the dry season.

During the wet season in Manaus, aerosol scattering $(450 \mathrm{~nm})$ and absorption $(637 \mathrm{~nm})$ coefficients averaged, respectively, $14 \pm 22$ and $0.9 \pm 0.8 \mathrm{Mm}^{-1}$. Both optical coefficients were greatly increased during the dry season, averaging $58 \pm 58 \mathrm{Mm}^{-1}$ and $4.1 \pm 3.8 \mathrm{Mm}^{-1}$, correspondingly. Angstrom exponents for scattering were lower during the wet season $(1.6 \pm 0.4)$ in comparison to the dry season $(1.9 \pm 0.2)$, which is consistent with the shift from biomass burning aerosols to biogenic and dust aerosols, predominant in the coarse mode. Single scattering albedo (at $637 \mathrm{~nm}$ ), did not show a significant seasonal variation, averaging $0.86 \pm 0.06$ and $0.86 \pm 0.04$, respectively for wet and dry season.
In Porto Velho, even in the wet season it was possible to observe a strong impact from anthropogenic sources. Very high biomass burning aerosols in the dry season were measured. $\mathrm{PM}_{2.5}$ aerosol concentrations of about $300 \mathrm{ug} / \mathrm{m}^{2}$ were measured in August and September for most of the years. Black carbon were measured at 20 $\mathrm{ug} / \mathrm{m}^{3}$ in the dry season, showing strong aerosol absorption. Very high aerosol light scattering coefficients above $300 \mathrm{Mm}^{-1}$ were measured.

In terms of trace elements, Table 1 provides the average elemental concentrations in $\mathrm{ng} / \mathrm{m}^{3}$ for trace elements measured in Manaus. It is possible to observe the very low elemental concentrations for $\mathrm{V}, \mathrm{Ni}, \mathrm{Pb}$ and other tracers of anthropogenic pollution. PM refers to the aerosol mass concentration and $\mathrm{BC}$ for the black carbon component.

In Manaus during January-April a significant influx of Sahara dust aerosol was observed (Baars et al., 2011). This long range transport happens when the ITCZ is South of Manaus, allowing air masses from Tropical Africa to enter South America, transporting dust with smoke from biomass burning in Africa.

Tab.1 Average concentrations in $\mathrm{ng} / \mathrm{m}^{3}$ for trace elements in Manaus for wet and dry seasons. Fine mode fraction is represented by $\mathrm{PM}_{2.5}$ (particles less than 2,5 micrometers). The term "Coarse Mode" refers to particles with diameter $2.5<\mathrm{dp}<10$ micrometers. PM refers to the aerosol mass concentration and BC for the black carbon component

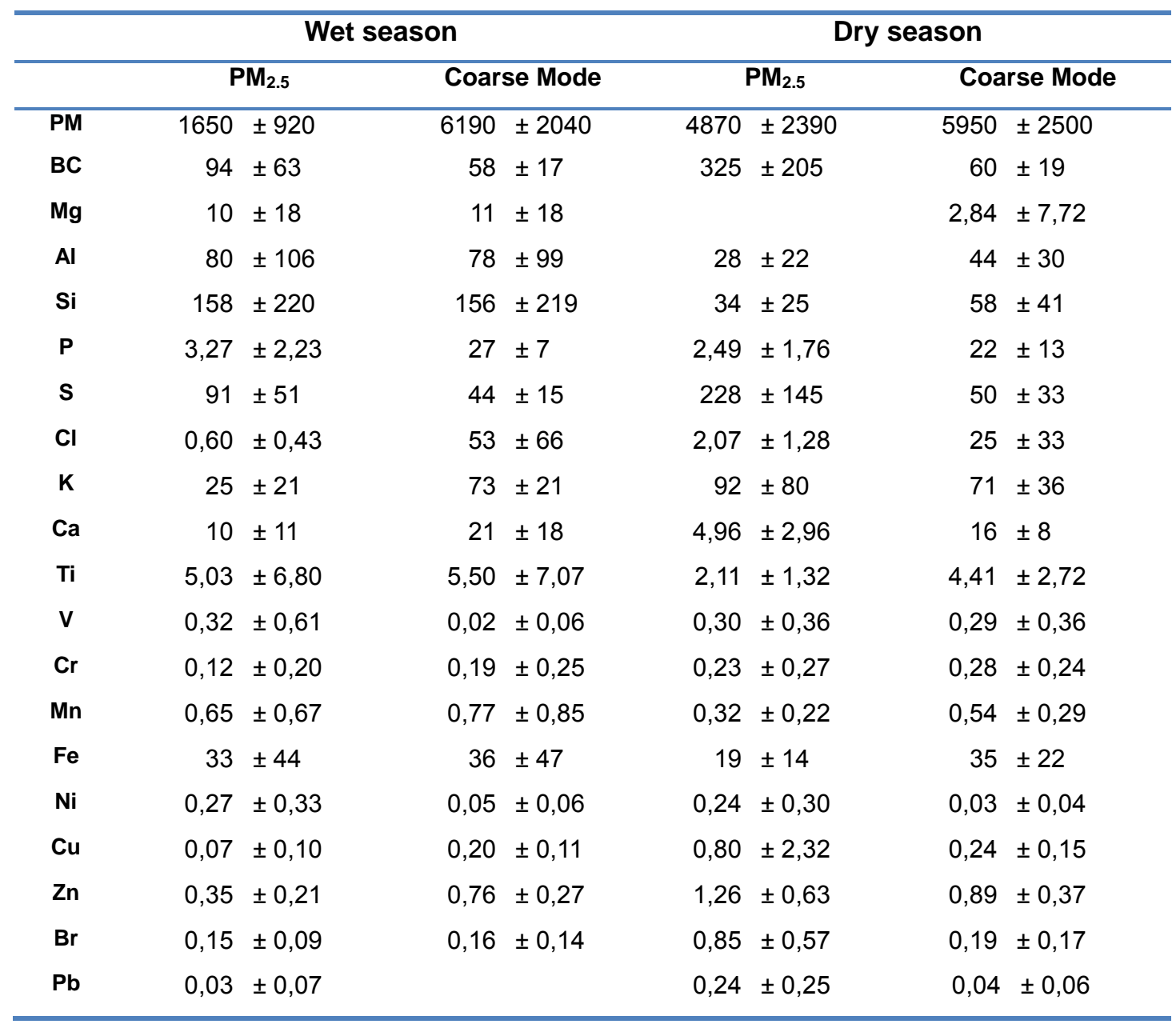


Tab.2 Average trace element concentrations in $\mathrm{ng} / \mathrm{m}^{3}$ for some selected trace elements in Manaus and Porto Velho and Manaus. Concentrations were measured for $\mathrm{PM}_{10}$ aerosols

\begin{tabular}{c|c|c|c|c}
\hline & \multicolumn{2}{c}{ Porto Velho } & \multicolumn{2}{c}{ Manaus } \\
\hline Element & Dry Season & Wet Season & Dry Season & Wet Season \\
$\mathbf{C r}$ & $0.5 \pm 0.5$ & $0.1 \pm 0.1$ & $0.3 \pm 0.2$ & $0.4 \pm 0.2$ \\
$\mathbf{N i}$ & $0.1 \pm 0.1$ & $0.1 \pm 0.1$ & $0.4 \pm 0.3$ & $0.4 \pm 0.3$ \\
$\mathbf{C u}$ & $1.0 \pm 0.4$ & $0.4 \pm 0.5$ & $5.0 \pm 8.6$ & $5.1 \pm 6.7$ \\
$\mathbf{P b}$ & $2.7 \pm 2.5$ & $0.9 \pm 0.7$ & $1.9 \pm 0.9$ & $1.6 \pm 0.7$ \\
$\mathbf{A l}$ & $121.4 \pm 89.2$ & $24.3 \pm 21.4$ & $14.8 \pm 17.7$ & $29.8 \pm 30.9$ \\
$\mathbf{F e}$ & $120.3 \pm 86.6$ & $36.3 \pm 77.5$ & $9.5 \pm 10.5$ & $127 \pm 16$ \\
\hline
\end{tabular}

The two sites show very different aerosol concentrations, as can be observed in Table 2. Lead concentrations from 1 to $3 \mathrm{ng} / \mathrm{m}^{3}$ were observed, and are associated with natural $\mathrm{Pb}$ levels in Amazonia. The fine mode aerosol concentration (PM2.5) for Manaus averages a low $1.9 \pm$ $1.3 \mu \mathrm{g} / \mathrm{m}^{3}$ and for Porto Velho, $8.7 \pm 7.0 \mu \mathrm{g} / \mathrm{m}^{3}$. For the coarse mode, we observed in Manaus a concentration of $4.2 \pm 2.2 \mu \mathrm{g} / \mathrm{m}^{3}$ and for Porto Velho $10 \pm 6.2 \mu \mathrm{g} / \mathrm{m}^{3}$. The fine mode black carbon concentrations show an even large difference between the two sites: $144 \pm 110 \mathrm{ng} / \mathrm{m}^{3}$ in Manaus and $861 \pm 520 \mathrm{ng} / \mathrm{m}^{3}$ for Porto Velho.

Positive Matrix Factorization (PMF) was used to separate the different aerosol components. In general, for fine and coarse mode and wet and dry season, 3 aerosol components could be observed: 1) Natural biogenic aerosol; 2) biomass burning component; 3) Soil dust both locally and long range transported Sahara dust.

\section{Conclusions}

This study presents long term trace element concentrations in two sites in Amazonia, one of them (Manaus) showing very low background concentrations. The site in Porto Velho, Rondonia shows that land use change increase aerosol concentrations very significant. But for some heavy metals such as lead, even in perturbed regions in Amazonia, concentrations are much lower than other continental regions. The aerosol in Amazonia is mostly organic (approx. 85\% of aerosol mass) (Martin et al., 2010).

In July 2012, mercury measurements will start continuously in Manaus, in order to understand the natural and long range transported components of $\mathrm{Hg}$, associated with aerosols and key trace gases.

\section{Acknowledgements}

The authors thank the financial supports from FAPESP, AEROCLIMA Thematic project, from $\mathrm{CNPq}$ and INCT-MC funding. This work was performed under the framework of the LBA (The Large Scale Biosphere Atmosphere Experiment in Amazonia), coordinated by INPA (The Brazilian National Institute for Research in Amazonia). Part of this project was funded by the FP6 EUCAARI project.

\section{References}

Davidson, Eric A., A. C. de Araújo, P. Artaxo, J. K. Balch, I. F. Brown, M. M. da C. Bustamante, M. T. Coe, R. S. DeFries, M. Keller, M. Longo, J. W. Munger, W. S., B. Soares-Filho, C. M. Souza Jr., S. C. Wofsy. The Amazon Basin in Transition. Nature, 481, 321-328, doi:10.1038/nature10717, Jan 19, 2012..

Martin, S.T., M. P. Artaxo, et al. An overview of the Amazonian Aerosol Characterization Experiment 2008 (AMAZE-08). Atmos. Chem. Phys.- ACP, Vol. 10, pp. 18139-18195. 2010.

Baars, H., A. Ansmann, D. Althausen, R. Engelmann, P. Artaxo, T. Pauliquevis, R. Souza. Further evidence for a significant smoke transport from Africa to Amazonia during the wet season. Geophysical Research Letters, Vol. 38, Article number L20802, DOI: 10.1029/2011GL049200. 2011.

Kulmala, M., Artaxo, P., et al., General Overview: European Integrated project on Aerosol Cloud Climate and Air Quality interactions (EUCAARI) integrating aerosol research from nano to global scales. Atmos. Chem. Phys., 11, 13061-13143, 2011. 